\title{
Molecular characterization and in vitro differentiation of feline progenitor-like amniotic epithelial cells
}

\author{
Lucia Rutigliano ${ }^{1 \dagger}$, Bruna Corradetti ${ }^{2 \dagger}$, Luisa Valentini ${ }^{1}$, Davide Bizzaro ${ }^{2}$, Aurora Meucci ${ }^{3}$, Fausto Cremonesi ${ }^{3,4^{*}}$ \\ and Anna Lange-Consiglio ${ }^{3}$
}

\begin{abstract}
Introduction: While amniotic mesenchymal cells have been isolated and characterized in different species, amniotic epithelial cells (AECS) have been found only in humans and horses and are recently considered valid candidates in regenerative medicine. The aim of this work is to obtain and characterize, for the first time in the feline species, presumptive stem cells from the epithelial portion of the amnion (AECs) to be used for clinical applications.
\end{abstract}

Methods: In our study, we molecularly characterized and induced in vitro differentiation of feline AECs, obtained after enzymatic digestion of amnion.

Results: AECs displayed a polygonal morphology and the mean doubling time value was $1.94 \pm 0.04$ days demonstrating the high proliferating capacity of these cells. By RT-PCR, AECs expressed pluripotent (Oct4, Nanog) and some mesenchymal markers (CD166, CD44) suggesting that an epithelial-mesenchymal transition may occur in these cells that lack the hematopoietic marker CD34. Cells also showed the expression of embryonic marker SSEA-4, but not SSEA-3, as demonstrated by immunocytochemistry and flow cytometry. Moreover, the possibility to use feline AECs in cell therapies resides in their low immunogenicity, due to the absence of MHC-Il antigen expression. After induction, AECs differentiated into the mesodermic and ectodermic lineages, demonstrating high plasticity.

Conclusions: In conclusion, feline AECs appear to be a readily obtainable, highly proliferative, multipotent and non-immunogenic cell line from a source that may represent a good model system for stem cell biology and be useful in allogenic cell-based therapies in order to treat tissue lesions, especially with loss of substance.

\section{Introduction}

The main applications of mesenchymal stem cells (MSCs) in human medicine are in the therapy of hematological disorders, cardiovascular degenerative diseases, genetic and neurological disorders, and in tissue engineering [1], but to date there are few clinical advances in other pathologies. Two essential factors are necessary to promote the study in regenerative medicine: a good animal model and an efficient source of stem cells.

\footnotetext{
* Correspondence: fausto.cremonesi@unimi.it

${ }^{\dagger}$ Equal contributors

${ }^{3}$ Large Animal Hospital, Reproduction Unit, Università degli Studi di Milano, Lodi, Italy

${ }^{4}$ Department of Veterinary Science for Animal Health, Production and Food Safety, Università degli Studi di Milano, Milano, Italy

Full list of author information is available at the end of the article
}

Since many pathologies are very difficult to study in human medicine, the domestic cat could offer an attractive animal model in order to explore different diseases with similarities to the human ones, as well as hereditary conditions (for example, autosomal dominant polycystic kidney disease) [2], hereditary retinal blindness [3], inherited muscular dystrophy [4], Niemann-Pick disease type C [5], diabetic neuropathy [6], immunodeficiency or viral diseases $[7,8]$. Moreover, since the cat genome project is nearly complete, the establishment of pluri/multipotent feline stem cells would facilitate targeting specific genetic loci, and generating additional useful disease models in the cat itself [9].

Regarding the stem cell reservoirs, the most characterized sources of MSCs are bone marrow (BM) [10-17] and the adipose tissue $[12,17]$. Also, in 2002, MSCs from

\section{Biomed Central}


$\mathrm{BM}$ in the cat were isolated for the first time and these cells appeared to be very similar to those obtained from rodent and human sources [18], but the procedures employed to isolate these tissues are invasive and cells are usually obtained with low efficiency [18-20].

Extra-fetal tissues could offer the possibility of getting over the limitations of adult stem cell sources [1,21-23]. Indeed, umbilical cord blood, umbilical cord matrix, amnion and amniotic fluid could provide a large amount of cells without risks for the donor and in an inexpensive and non-invasive way, since they are discarded at delivery, or can also be collected after cesarean section or in case of ovario-hysterectomy of pregnant uteri. This is a great concern for regenerative medicine, especially if there is the chance to cryogenically bank them [24,25].

Among extra-fetal tissues, recently, amniotic membrane appeared an important stem cell source in different species, including human [26], horse [23,27], sheep [28], dog [29] and cat [30]. The amniotic epithelium layer, while originating from the trophectoderm as other parts of fetal membranes, has the peculiarity of being continuous with the epiblast [31]. For this reason it may probably preserve some of the characteristics of the epiblast, like pluripotency [32], as confirmed by the expression of different pluripotent stem cell-specific transcription factors, such as Sox2, Nanog, Oct4 and Rex1 [27,32-36]. Amniotic epithelial cells (AECs) have been isolated and characterized in different species, such as in the human [36], horse [27] and sheep [37] and their pluripotency and plasticity are demonstrated by in vitro differentiation into the cell lines of the three germ layers $[21,26,27,32,33,38-40]$. The potential application of AECs in cell-based therapies relies not only on their pluripotent features, but also on their immunogenic characteristics. In fact, they do not express Major Histocompatibility Complex (MHC) Class II antigens $[21,27,41,42]$. In addition, AECs actively secrete a number of immunosuppressive factors with a consequent failure of allogeneic lymphocyte responsiveness, which may support survival following transplantation and engraftment $[21,39,41-44]$.

The chance to characterize feline stem cells could be helpful in cell-based therapies in human medicine for the pathologies described above, but also in feline species to treat tissue lesions especially characterized by loss of substances. Moreover, these cells could also improve the efficiency of interspecies somatic cell nuclear transfer for preserving endangered felids [45] and could be used in drug testing in therapeutic intervention, and auto/allo/xenogenic transplantation.

Considering the reported context, in this study we isolated and characterized, for the first time, in terms of morphology, specific stemness and pluripotent markers, proliferative and differentiative potential, the AECs from the domestic cat.

\section{Materials and methods Amnion collection}

Uteri were recovered from three pregnant queens at 40 to 45 days of gestational age, brought to the veterinary hospital by their owners to be spayed. In this study, after approval by the Ethical Committee of the University of Milan and the owner's written consent, all procedures were conducted following standard veterinary practice and in accordance with 2010/63 EU directive on animal protection and Italian Law (D.L. No. 116/1992). According to the ethical guidelines, during ovariohysterectomy, care was given to maintain fetuses in the depressed state from maternal anesthesia until vital signs (heart beats) disappeared, as assessed by intra-surgical ultrasonography, before removal of the gravid uterus.

Samples of allanto-amnion were kept in a $4^{\circ} \mathrm{C}$ in phosphate-buffered saline (PBS) for not more than $24 \mathrm{~h}$. The amniotic membrane of each sample was mechanically separated from the allantois and was cut into small pieces before enzymatic digestion to isolate presumptive AECs.

\section{Isolation of amniotic epithelial cells and cell culture}

Amnion fragments were washed twice in Hank's Balanced Salt Solution (Euroclone, Milano, Italy. ECB-4007 L) supplemented with penicillin $100 \mathrm{UI} / \mathrm{ml} /$ streptomycin $100 \mu \mathrm{g} /$ $\mathrm{ml}$ (Sigma, Aldrich, Milano, Italy. P-0781), and then incubated for nine minutes at $37^{\circ} \mathrm{C}$ in a pre-warmed solution of PBS containing 2.4 U/ml dispase (Becton Dickinson and Company, Milano, Italy. 354235). After that, the fragments were digested with $0.05 \%$ trypsin $/ 0.02 \%$ EDTA (Euroclone, ECB3052D) for 40 minutes at $37^{\circ} \mathrm{C}$, in order to obtain AECs. The suspension was filtered using $80 \mu \mathrm{m}$ filters (Millipore, Milan, Italy), and trypsin-undigested amnion fragments were digested again with pre-warmed $0.25 \%$ trypsin (Sigma, T-4049), strongly shaking for one to two minutes. After filtering again, trypsin in the suspension was neutralized with high glucose-Dulbecco's modified Eagle's medium (HG-DMEM; Euroclone, ECB7501L), supplemented with $10 \%$ heat-inactivated fetal bovine serum (FBS; Sigma Aldrich, F-7678) and AECs were collected by centrifugation at $200 \mathrm{x}$ g for 10 minutes.

Cells were cultured in HG-DMEM supplemented with 10\% FBS, $10 \mathrm{ng} / \mathrm{ml}$ epidermal growth factor (Sigma, E-9644), penicillin $100 \mathrm{UI} / \mathrm{ml} /$ streptomycin $100 \mu \mathrm{g} / \mathrm{ml}$ (Sigma, P-0781), $0.25 \mu \mathrm{g} / \mathrm{ml}$ amphotericin B (Sigma, A5955), 2 mM L-glutamine (Sigma, G-7513) and maintained at $5 \% \mathrm{CO}_{2}$, and $38.5^{\circ} \mathrm{C}$ for the experiments described below. Medium was replaced after 72 hours for the first time to remove non-adherent cells and then it was replaced twice weekly or according to the experimental design. Adherent cells were detached with $0.05 \%$ trypsin/0.02\% EDTA (Euroclone, ECB3052D) just prior to reaching plate confluence $(80 \%)$ and then reseeded for culture maintaining. The cells were expanded for 10 passages. 
Proliferation assays: growth curve and doubling time analysis To obtain the cell proliferation growth curve, cells at passage (P) 0 and P3 were seeded into six-well tissue culture dishes (Costar ${ }^{\oplus}$ Corning, NY, USA. 3516) at a density of $1 \times 10^{3}$ cells $/ \mathrm{cm}^{2}$. Every 2 days, through 14 days of culture, one well of the six-well dishes was trypsinized, and a cell count was performed. The number of viable cells was obtained by the Trypan blue dye exclusion method using a Burker chamber.

Doubling time (DT) analysis of AECs was also assessed. Culture passages from P1 to P10 were performed every four days and the number of viable cells for each passage was determined by the Trypan blue dye exclusion method using a Burker chamber. The population DT was obtained for each passage using the formula DT $=C T / C D$, where CT (culture time) is the time between passage " $\mathrm{n}$ " and passage " $\mathrm{n}+1$ " and CD (cell doubling) $=\ln (\mathrm{Nf} / \mathrm{Ni}) / \ln 2$, where $\mathrm{Ni}$ represents the seeded cells number and $\mathrm{Nf}$ the harvested cells number.

\section{Colony-forming unit assay}

Colony-forming unit (CFU) assays were performed at P0 on freshly isolated cells at different densities (100, 250, 500 and 1,000 cells $/ \mathrm{cm}^{2}$ ). Cells were plated in six-well plates and cultured in $5 \% \mathrm{CO}_{2}$ and $90 \%$ humidity at $38.5^{\circ} \mathrm{C}$ for two weeks in HG-DMEM-supplemented medium. Then, colonies were fixed with $4 \%$ formalin and stained with $1 \%$ methylene blue (Serva, Heidelberg, Germany) in $10 \mathrm{mM}$ borate buffer, pH 8.8 (Fluka BioChemika, Buchs, Swizerland) at room temperature, and washed twice. Colonies formed by 16 to 20 nucleated cells were counted under a BX71 microscope (Olympus Italia, Srl, Milano, Italy).

\section{RNA extraction and reverse transcription-polymerase chain reaction (RT-PCR)}

Total RNA was extracted from feline amnion-derived cells at each passage, using TRIReagent (Sigma). Samples were then treated with DNAse (Sigma, D4263) in order to avoid DNA contamination. Both steps were performed according to the manufacturers' specifications.

RNA concentration and purity were measured by Nanodrop Spectrophotometer (Nanodrop ${ }^{\circledR}$ ND1000 Thermo Scientific, Wilmington, USA). cDNA was synthesized from total RNA (500 ng) using Taqman Reverse Transcription reagents kit (Applied Biosystems, Life Tecnologies, Monza, Italy. 4304134).

Qualitative polymerase chain reaction (PCR) was performed in a $25 \mathrm{ml}$ final volume with JumpStart Taq ReadyMix (Sigma-Aldrich, P2893) under the following conditions: initial denaturation at $94^{\circ} \mathrm{C}$ for 2 minutes, 32 cycles at $94^{\circ} \mathrm{C}$ for 30 seconds (denaturation), 55 to $60^{\circ} \mathrm{C}$ for 30 seconds (annealing), $72^{\circ} \mathrm{C}$ for 2 minutes (elongation) and final elongation at $72^{\circ} \mathrm{C}$ for 5 minutes.
The expression of the following set of genes was evaluated for molecular characterization before in vitro differentiation of cells: POU class 5 homeobox 1 (POU5F1 alias Oct4), Nanog homeobox, as pluripotent-ESCs markers; phagocitic glycoprotein I (CD44), ALCAM (CD166), integrin beta-1 (CD29), 5' nucleotidase ecto (NT5E alias CD73), thymus cell surface antigen theta-1 (Thy1 alias CD90), as mesenchymal markers; Gp 105 to 120 (CD34), as hematopoietic marker; Major Histocompatibility Complex I and II (MHCI, $M H C-I I)$, as immunogenic markers.

Feline specific primers were initially designed with the open source PerlPrimer software (v1.1.20, Parkville, Australia) based on NCBI Felis catus sequences or on mammal multi-aligned sequences, and subsequently manually improved. Primers were used at $200 \mathrm{nM}$ final concentration.

To test in vitro cell differentiation, the following set of markers was used: bone gamma-carboxyglutamate osteocalcin $(O C N)$ and osteopontin $(O P N)$ for osteogenic differentiation; adiponectin (ADIPQ) and peroxisome proliferator-activated receptor $\gamma(P P A R-\gamma)$ for adipogenic differentiation; aggrecan $(A C A N)$ and collagen type 2 chain $\alpha 1$ (COL2A1) for chondrogenic differentiation; nestin $(N E S)$ for neurogenic differentiation. Feline mature tissues (bone, fat, cartilage and spinal cord) were used as positive controls for the expression of osteogenic, adipogenic, chondrogenic and neurogenic markers.

Glyceraldehyde 3-phosphate dehydrogenase (GAPDH) was used as reference a gene.

The sequences of each gene are shown in Table 1.

\section{In vitro multipotent differentiation}

In order to test their multipotent differentiation potential, cells at P3 were seeded at a density of $1 \times 10^{3} / \mathrm{cm}^{2}$ in six-well tissue culture dishes.

\section{Osteogenic differentiation}

For osteogenic differentiation, cells were cultured in HGDMEM, supplemented with $10 \% \mathrm{FBS}, 100 \mathrm{U} / \mathrm{ml}$ penicillin, $100 \mu \mathrm{g} / \mathrm{ml}$ streptomycin, $0.25 \mu \mathrm{g} / \mathrm{ml}$ amphotericin $\mathrm{B}, 2$ $\mathrm{mM} / \mathrm{l} \mathrm{L}$-glutamine, $10 \mathrm{mM} \beta$-glycerophosphate (Sigma, 50020), $0.1 \mu \mathrm{M}$ dexamethasone (Sigma, D2915) and 250 $\mu \mathrm{M}$ ascorbic acid (Sigma, A8960). The osteogenic differentiation was assessed by incubating cells for up to three weeks at $38.5^{\circ} \mathrm{C}$ with $5 \% \mathrm{CO}_{2}$. Non-induced control cells were cultured for the same time with standard medium (HG-DMEM supplemented with 10\% FBS, $100 \mathrm{U} / \mathrm{ml}$ penicillin, $100 \mu \mathrm{g} / \mathrm{ml}$ streptomycin, $0.25 \mu \mathrm{g} / \mathrm{ml}$ amphotericin B, $2 \mathrm{mM} / \mathrm{l}$ L-glutamine). The medium was changed twice weekly. Presence of calcium deposits in differentiated cells was verified by von Kossa staining.

\section{Adipogenic differentiation}

For adipogenic differentiation, cells were cultured in HG-DMEM, supplemented with 10\% FBS, $100 \mathrm{U} / \mathrm{ml}$ 
Table 1 Oligonucleotide sequences used for RT-PCR analysis

\begin{tabular}{|c|c|c|c|}
\hline & Gene & Primers & Product size \\
\hline \multirow[t]{2}{*}{ Housekeeping gene } & GAPDH & Forward, 5' - ACGATGACATCAAGAAGGTG - 3' & $180 \mathrm{bp}$ \\
\hline & & Reverse, $5^{\prime}$ - CATACCAGGAAATGAGCTTG - 3' & \\
\hline \multirow[t]{4}{*}{ Pluripotent markers } & Oct4 & Forward, 5' - GGAGTCCCAGGACATCAAAG - 3' & $285 \mathrm{bp}$ \\
\hline & & Reverse, 5' - GCCTGCACAAGTGTCTCTGC - 3' & \\
\hline & Nanog & Forward, 5' - ACGGATCCAGCTCAGCCCCA - 3' & $192 \mathrm{bp}$ \\
\hline & & Reverse, 5' - GGGGCTGCCCTGAGCAAGTA - 3' & \\
\hline \multirow[t]{10}{*}{ Mesenchymal markers } & CD44 & Forward, 5' - TGGGTTGTTTGGCATCCAGTGC - 3' & $100 \mathrm{bp}$ \\
\hline & & Reverse, 5' - CGTTITCTTCAGTTGGTTCCCAGCC - 3' & \\
\hline & CD166 & Forward, 5' - ACTGGCAGTGGAAGCGTCAT - 3' & $275 \mathrm{bp}$ \\
\hline & & Reverse, 5' - CAGCAAGGAGGAGACCA - 3' & \\
\hline & CD29 & Forward, 5' - GGAAACTTGGTGGCATTGTT - 3' & $180 \mathrm{bp}$ \\
\hline & & Reverse, 5' - GTTCCTTGTAAACGGGCTGA - 3' & \\
\hline & CD73 & Forward, $5^{\prime}$ - AGCAAAGGGGCCACTAGCATCT - 3' & $233 \mathrm{bp}$ \\
\hline & & Reverse, 5' - ACCCGAATGTCCCAGTGCAA - 3' & \\
\hline & CD90 & Forward, 5' - GAGCACACGTACCGCTCCCG - 3' & $233 \mathrm{bp}$ \\
\hline & & Reverse, 5' - AGCAGCAGCAGCAGCATCCA - 3' & \\
\hline \multirow[t]{2}{*}{ Hematopoietic marker } & CD34 & Forward, 5' - CTITAACTGTCACGGCGTTT - 3' & $198 \mathrm{bp}$ \\
\hline & & Reverse, 5' - TGACTCGGGAACATTTGATT - 3' & \\
\hline \multirow[t]{4}{*}{ Immunological markers } & $M H C-1$ & Forward, 5' - CATCACCCTGAGATGGGAGC - 3' & $176 \mathrm{bp}$ \\
\hline & & Reverse, 5' - TGGGTACTGTCGTCGCGTG - 3' & \\
\hline & MHC-II & Forward, 5' - TCCGGAATCAGAAAGGACAC - 3' & $172 \mathrm{bp}$ \\
\hline & & Reverse, 5' - GGCAAACCAAATCCTGAGAA - 3' & \\
\hline \multirow[t]{4}{*}{ Osteogenic markers } & OCN & Forward, 5' - CTGCCTCTGCCTGGCTGGTC - 3' & $120 \mathrm{bp}$ \\
\hline & & Reverse,5' - TAGCGCCGGAGCCTCCTCAC - 3' & \\
\hline & OPN & Forward, 5' - ACTGGTCACTGATTITCCCACGGA - 3' & $100 \mathrm{bp}$ \\
\hline & & Reverse, 5' - AACCACACTATCACCTCGGCCA - 3' & \\
\hline \multirow[t]{4}{*}{ Adipogenic markers } & $A D P Q$ & Forward, 5' - TGAGAAAGGAGATCCAGGTC - 3' & $308 \mathrm{bp}$ \\
\hline & & Reverse, 5' - TCAAGTAGACTGTGATGTGG - 3' & \\
\hline & PPAR- $\gamma$ & Forward, 5' - CATGGTTGACACAGAGATGC - 3' & $239 \mathrm{bp}$ \\
\hline & & Reverse, 5' - GCTCCACTTTGATTGCACTITG -3' & \\
\hline \multirow[t]{4}{*}{ Chondrogenic markers } & ACAN & Forward, 5' - AAGTGGAGCCGCGTTTCCAAGG - 3' & $163 \mathrm{bp}$ \\
\hline & & Reverse, 5' - AGTCATTGGAGCGCAGGTTCTGG - 3' & \\
\hline & COL2A1 & Forward, 5' - AGTTGGGAGTAATGCAAG - 3' & $294 \mathrm{bp}$ \\
\hline & & Reverse, 5' - GATAACCTCTGTGACCTTTG - 3' & \\
\hline \multirow[t]{2}{*}{ Neurogenic marker } & NES & Forward, 5' - AAACAGGGCCTACAGAG - 3' & $293 \mathrm{bp}$ \\
\hline & & Reverse, 5' - ACAGGTGTCTCAAGGGTAG - 3' & \\
\hline
\end{tabular}

penicillin, $100 \mu \mathrm{g} / \mathrm{ml}$ streptomycin, $0.25 \mu \mathrm{g} / \mathrm{ml}$ amphotericin B, $2 \mathrm{mM} / \mathrm{l}$ L-glutamine, $10 \mu \mathrm{g} / \mathrm{ml}$ insulin (Sigma I-6634), $150 \mu \mathrm{M}$ indomethacin (Sigma I-7378), $1 \mu \mathrm{M}$ dexamethasone and $500 \mu \mathrm{M}$ IBMX (3-isobutyl-methylxanthine, Sigma I-7018) and the adipogenic differentiation was assessed by incubating cells for up to three weeks at $38.5^{\circ} \mathrm{C}$ with $5 \% \mathrm{CO}_{2}$. Non-induced control cells were cultured for the same time with standard medium. The medium was changed twice weekly. Differentiation was evaluated by Oil Red-O staining (Sigma, O0625), which dye intracytoplasmatic lipid droplets.

\section{Chondrogenic differentiation}

For chondrogenic differentiation, cells were cultured in DMEM low-glucose, containing $100 \mathrm{U} / \mathrm{ml}$ penicillin, $100 \mu \mathrm{g} / \mathrm{ml}$ streptomycin, $0.25 \mu \mathrm{g} / \mathrm{ml}$ amphotericin $\mathrm{B}$, $2 \mathrm{mM} / \mathrm{l} \mathrm{L}$-glutamine, $100 \mathrm{nM}$ dexamethasone, $50 \mu \mathrm{g} / \mathrm{ml}$ L-ascorbic acid 2-phosphate, $1 \mathrm{mM}$ sodium pyruvate 
(BDH, Chemicals, Poole, UK. 44094BN), $40 \mu \mathrm{g} / \mathrm{ml}$ proline, ITS (insulin $5 \mu \mathrm{g} / \mathrm{ml}$, transferrin $5 \mu \mathrm{g} / \mathrm{ml}$, selenous acid 5 $\mathrm{ng} / \mathrm{ml}$; Sigma, I3146) and $5 \mathrm{ng} / \mathrm{ml}$ transforming growth factor- $\beta 3$ (Peprovet, DBA Milano, Italy. 100-36E). The chondrogenic differentiation was assessed by incubating cells for up to three weeks at $38.5^{\circ} \mathrm{C}$ with $5 \% \mathrm{CO}_{2}$. Noninduced control cells were cultured for the same time with standard medium. The medium was changed twice weekly.

Differentiation was evaluated by Alcian blue (Sigma, 89640) staining.

\section{Neurogenic differentiation}

The neurogenic differentiation was performed by incubating cells in a pre-induction medium consisting of HG-DMEM, $20 \%$ FBS and $1 \mathrm{mM} \beta$-mercaptoethanol (Sigma, M7522) for $24 \mathrm{~h}$; then the neuronal induction was performed with a medium composed of HG-DMEM supplemented with $2 \%$ FBS, 2\% dimethylsulfoxide (Sigma, D-5879) and $200 \mu \mathrm{M}$ butylated hydroxyanisole (Sigma, B-1253) for three days. Non-induced control cells were cultured for the same time with standard medium. Differentiation was evaluated by Nissl staining to stain Nissl bodies.

The occurred differentiation was confirmed performing RT-PCR on undifferentiated (controls) and induced AECs (control cells) as described above.

\section{Detection of SSEA-3 and SSEA-4 markers by immunocyto- chemistry and flow cytometry}

To test the expression of SSEA-3 and SSEA-4, as embryonic markers, primary rat and mouse antibodies respectively were purchased from Abcam (Cambridge, MA, USA), while Alexafluor-488 conjugated secondary antibodies were from Invitrogen (Carlsbad, CA, USA). All products were used following the manufacturer's instructions.

\section{Immunocytochemical characterization}

For immunostaining, cells at P3 were fixed in 3.7\% paraformaldehyde (PFA) for 15 minutes and washed three times in PBS. After that, cells were blocked using $2 \%$ bovine serum albumin (BSA) in PBS for $4 \mathrm{~h}$ at $4^{\circ} \mathrm{C}$. Cells were incubated with primary antibodies overnight at $4^{\circ} \mathrm{C}$. After washing three times, cells were incubated with rabbit anti-mouse and anti-rat Alexa Fluor 488-conjugated secondary antibody (1:250 dilution) for $1 \mathrm{~h}$. Finally, for nuclear staining, cells were incubated for 15 minutes with Hoechst 33342 (1 mg/ml; Sigma) diluted 1:100 in PBS. The specificity of the immunostaining was tested by including negative controls, performed by use of nonimmune mouse and rat serum (Santa Cruz Biotechnology Inc., Heidelberg, Germany) in place of specific antisera, and omission of the primary antibody.

Images were captured on a BX 51 microscope (Olympus, Japan).

\section{Flow cytometry (FCM) analysis}

At P3, AECs $\left(2 \times 10^{6}\right.$ cells $\left./ \mathrm{ml}\right)$ were labeled with primary antibodies for SSEA-3 and SSEA-4 in 3\% BSA (BDH, VWR International Ltd., Poole, UK) in PBS for $45 \mathrm{mi}$ nutes at room temperature in the dark. After that, cells were washed in cold PBS and incubated with secondary AlexaFluor-488 conjugated antibodies (1:250) for $30 \mathrm{mi}-$ nutes at room temperature in the dark. Labeled cells were washed twice in ice cold PBS and analyzed using an Epics Coulter flow cytometer (Beckman Coulter-IL, Fullerton, CA, USA). A minimum of 10,000 cells were acquired for the evaluation of each antibody and analyzed in the FL1 channel. All analyses were based on control cells incubated with isotype-specific IgG or IgM to establish the background signal. Files analysis was performed using Weasel software v.2.5 available online (Parkville, Australia) [46].

\section{Statistical analysis}

Statistical analysis was performed using GraphPad Instat 3.00 for Windows (GraphPad Software, La Jolla, CA, USA). Three replicates for each experiment (growth curves, doubling times and CFU) were performed and the results are reported as mean standard deviation (SD). One-way analysis of variance (ANOVA) for multiple comparisons by Student-Newman-Keuls multiple comparison tests was used. CFU comparison among different cell plating densities inside each group was analyzed. $P<0.05$ was considered as significant.

\section{Results}

Amnion collection and isolation of amniotic epithelial cells Cells adhered to culture dishes and in the first culture displayed initial morphological heterogeneity with epithelial, fibroblastic-like and circular cells. Subsequently, a typical polygonal epithelial morphology was recognized. Moreover, clusters of rapidly expanding cells were observed.

Representative images are shown in Figure 1.

\section{Proliferation assay: growth curve and doubling time analysis}

Studying the growth curve of feline AECs it was possible to observe at P0 a slow plating efficiency with a lag phase of 48 hours compared to cells at P3 that showed an immediate and intensive log phase until the ninth day. In both curves there was a final plateau phase from the $9^{\text {th }}$ to the $14^{\text {th }}$ day (Figure 2).

At P1 and P2, the population DT was higher compared to the other passages, with mean values of $5.2 \pm$ 0.25 and $3.6 \pm 0.09$ days, respectively. From P3 to P10, the mean DT value was $1.25 \pm 0.14$ days. Differences were statistically significant comparing P1 with P2 $(P<0.05)$ and highly significant comparing $\mathrm{P} 1$ with the subsequent passages $(P<0.01)$ (Figure 2$)$. 


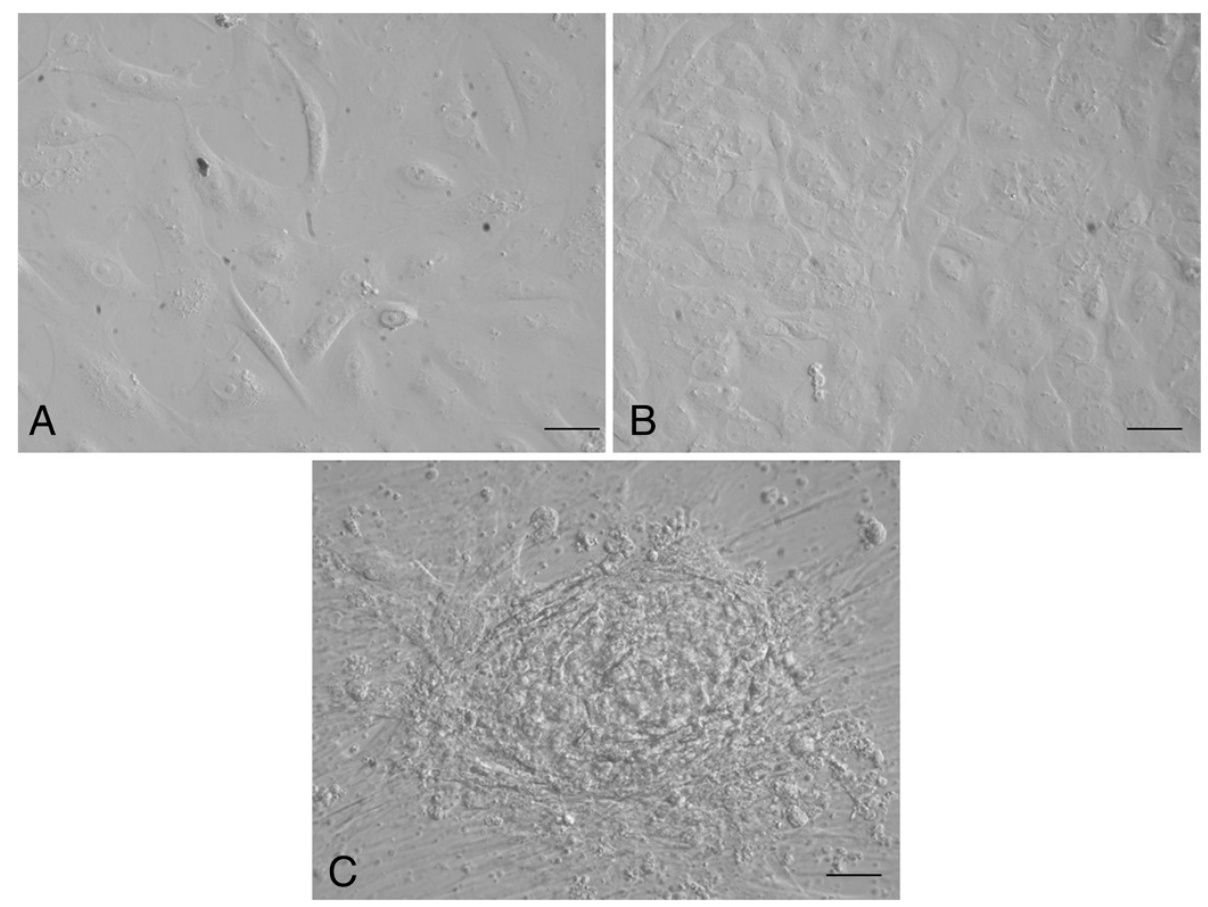

Figure 1 Cell morphology. (A) Monolayer of cells in first culture and (B) at passage 3 (P3); (C) Amniotic epithelial cells (AECs) with cluster. Magnification 20x; scale bar $=20 \mu \mathrm{m}$.

\section{Colony-forming unit assay}

The number of cell colonies formed was counted at P0 after seeding cells at different density $/ \mathrm{cm}^{2}$. AECs demonstrated a statistically significant increase in CFU frequency with increasing cell-seeding densities (Table 2).

\section{RNA extraction and RT-PCR analysis}

As shown by RT-PCR, AECs expressed the pluripotencyassociated markers Oct-4 and Nanog: mRNAs for Oct-4 were detected over the passages studies, whereas those for Nanog were only expressed at the first passages (P2 and P3) and surprisingly at P7. Cells also showed expression for some of the mesenchymal stem cell- (MSC-)associated markers (being positive for CD44 at each passage and for CD166 from P3 to P7) and lacked of the hematopoietic marker CD34. Expression for other MSC-specific markers (CD29, CD73 and CD90) has not been registered at any stage. $M H C-I$ expression was demonstrated in each cell population, whereas $M H C-I I$ was not. Figure 3 shows the expression of the specific genes evaluated.

\section{In vitro multipotent differentiation}

\section{Osteogenesis}

After three weeks of culture in osteogenic induction medium, feline AECs distinctly changed their morphology and were surrounded by calcium deposits positive to von Kossa staining. In controls, cells did not change in morphology and did not stain positively to von Kossa.

The osteogenic differentiation was confirmed by the expression of OPN and OCN mRNAs. A weak expression of $O C N$ was also registered in the controls (Figure 4A).

\section{Adipogenesis}

In cells induced to differentiate into adipocytes, the presence of intracytoplasmatic lipids droplets was evident after three weeks, whereas control cells showed no lipid deposits. Molecular analysis confirmed the induction revealing the expression of PPAR- $\gamma$, whereas mRNAs for adiponectin were not detected (Figure 4B).

\section{Chondrogenesis}

Cells grown in chondrogenesis-inducing medium stained positively for Alcian Blue, demonstrating a marked deposition of metachromatic extracellular matrix composed by glycosaminoglycans. Controls did not change in morphology and were negative to Alcian blue staining. RT-PCR showed that differentiated cells express $A C A N$ and $C O L 2 A 1$, confirming the induction (Figure 4C).

\section{Neurogenesis}

When induced into neurogenic lineage, cells showed an increased presence of Nissl bodies and displayed the typical neuronal morphology with axon- and dendritelike processes, as compared to the polygonal epithelial 


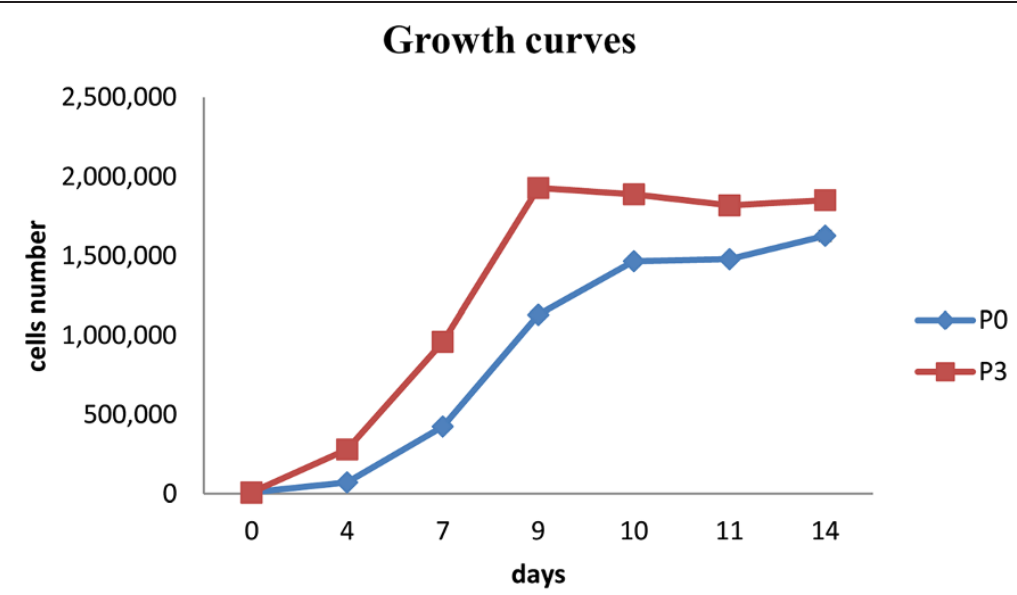

Doubling Time

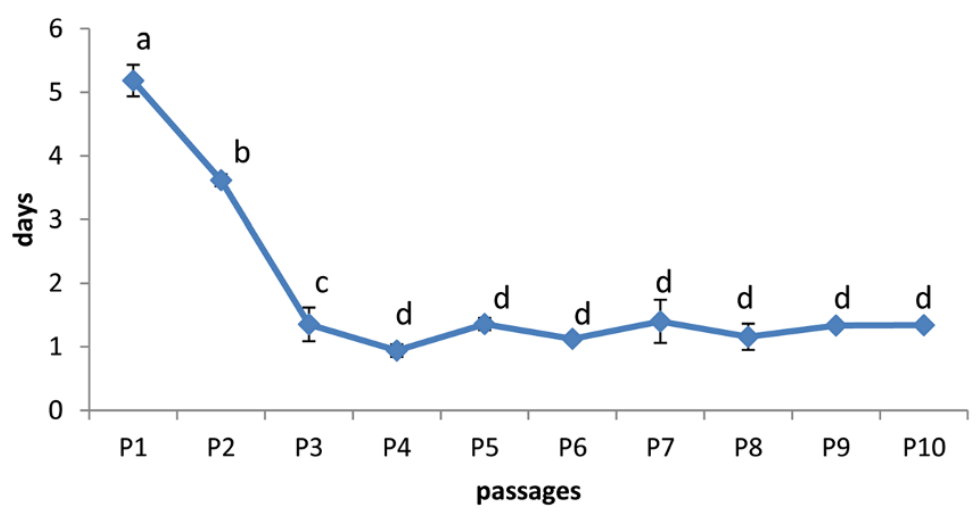

Figure 2 Proliferation assay. AECs growth curve at P1 and P3; doubling times at different passages during cell culture. Letters represent doubling time means statistically different. $\mathbf{a}, \mathbf{b}: P<0.05 ; \mathbf{c}, \mathbf{d}: P<0.01$.

morphology observed in cells cultured in basal conditions. RT-PCR confirmed the neurogenic differentiation (Figure 4D).

\section{Detection of SSEA-3 and SSEA-4 markers by immunocyto- chemistry and flow cytometry}

Only immunopositivity to the stem cell markers SSEA-4 was detected. AECs expressed this antigen on the cell surface (Figure 5A).

FCM analysis revealed that AECs were negative for SSEA-3 while $85 \%$ of cells showed SSEA-4 reactivity (Figure 5B).

Table 2 CFU assay

\begin{tabular}{lllll}
\hline & Density cells $/ \mathbf{c m}^{\mathbf{2}}$ & Total cells & CFU & 1 CFU each \\
\hline AECs & 100 & 950 & $1.82 \pm 0.72^{\mathrm{a}}$ & 521.98 \\
& 250 & 2,375 & $15.93 \pm 1.39^{\mathrm{b}}$ & 149.09 \\
500 & 4,750 & $20.54 \pm 2.72^{\mathrm{c}}$ & 231.25 \\
1,000 & 9,500 & $37.43 \pm 2.67^{\mathrm{d}}$ & 253.81 \\
\hline
\end{tabular}

Different small letters superscripts (a, b, c, d) indicate statistically different comparisons $(P<0.05)$ between cell densities in each group (amniotic epithelial cells (AECs)).

\section{Discussion}

The identification of the optimal source of stem cells represents a critical issue for cell therapy, in order to obtain a relevant amount of cells and to minimize risks for the donors and the recipients. For these purposes, amniotic membrane is a valid alternative, in particular for the isolation of epithelial cells [23,27,36,37]. Despite the importance of the domestic cat in studying human genetic and viral diseases, to our knowledge no studies have been performed on feline amniotic epithelial cells.

In the present study, for the first time, we have isolated and expanded AECs from feline amnion that is an extra-fetal tissue and thus retains higher proliferation and differentiation potential respect to cells deriving from adult compartments. Cells, easily isolated through enzymatic digestion, showed typical polygonal epithelial morphology and were able to be sub-cultured in vitro.

The proliferation study (growth curve) showed that AECs reached high plating efficiency at P3, as demonstrated by the short lag phase in respect to P0. This result was probably due to the fact that the first culture is composed of a heterogeneous cell population that 


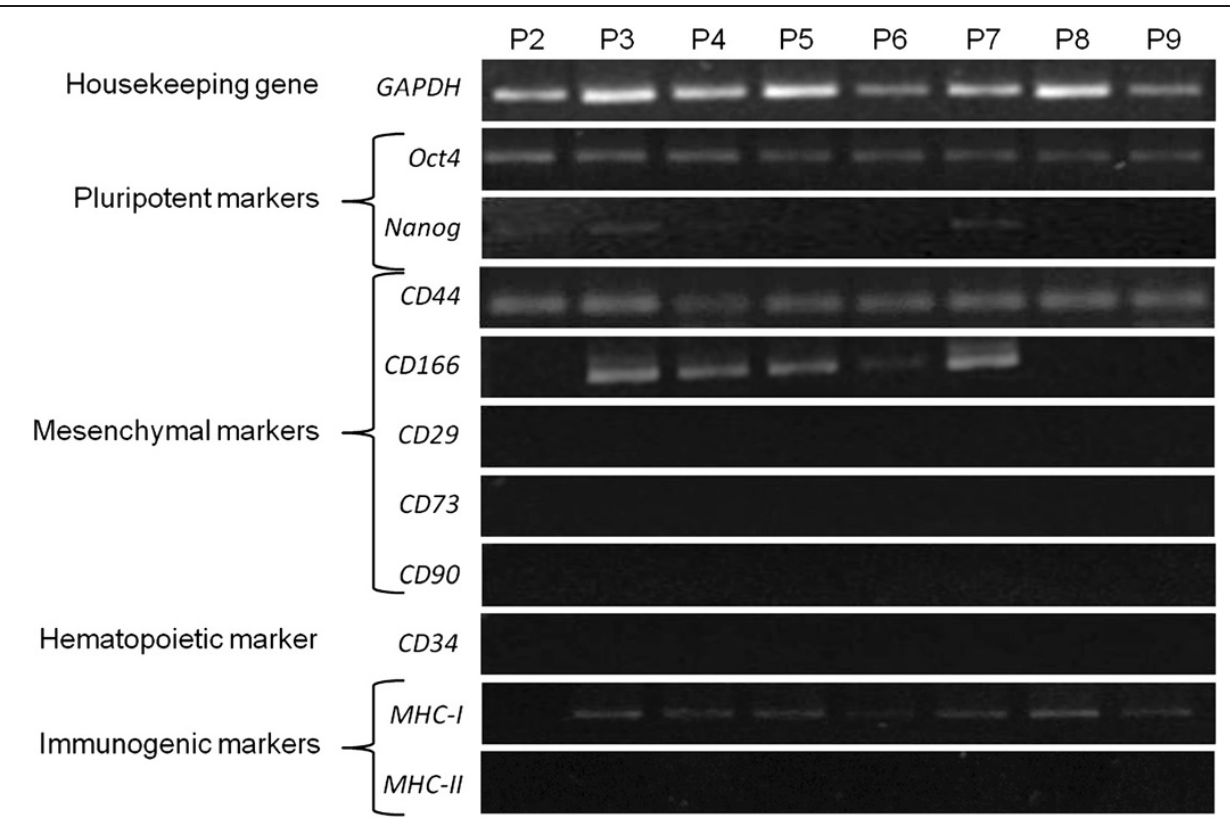

Figure 3 RT-PCR analysis. Pluripotent (Oct4 and Nanog), mesenchymal (CD44, CD166, CD29, CD73, CD90) and hematopoietic (CD34) specific gene expression on AECs from P1 to P9. Major Histocompatibility Complex (MHC) I and II gene expression is also reported. GAPDH was used as reference gene. AECs, amniotic epithelial cells.

possesses a lower potential, as MSCs. According to this, but in contrast with data reported in literature [36,38], the DT analysis revealed a high value for the first passages (P1: $5.19 \pm 0.25$ days; P2: $3.62 \pm 0.09$ days). To confirm our hypothesis, on the other hand, the initial heterogeneity of cell population was also recognized morphologically during the primary culture (at $\mathrm{P} 0$ ), when fibroblastic-like and circular cells were present. By the first passage, a selection of typical polygonal epithelial cells occurred and from P3 to P9 the proliferation rate increased with a mean DT value of $1.24 \pm 0.17$ days, suggesting that at P3 AECs reached the sufficient levels of homogeneity. This indicates the higher proliferating ability of the isolated AECs, in accordance with Miki et al. [38] and Parolini et al. [36] in humans, and with Lange-Consiglio et al. [27] in equine species, who reported robust proliferation at least up to P6.

When AECs were seeded at different densities, they were able to form clones with frequency that increased with the cell-seeding density, suggesting that paracrine signaling between cells at P0 occur [47]. Moreover, when AECs are kept in high-density cultures, small cell clusters or spheroid structures developed, showing that these cells did not have contact-inhibited cell growth and continue to proliferate after reaching $100 \%$ surface confluence, forming aggregates overlying the monolayer of confluent cells. Miki et al. $[32,34,38]$ report that the amniotic cells in monolayer may support the growth and maintain undifferentiated the amniotic cells of spheroid structures, possibly playing the role of an autologous feeder layer and providing secreted factors.

Molecular characterization by RT-PCR showed the expression of some of the pluripotency-associated transcription factors, as Oct4 at each of the passages studied, in agreement with data reported in previous studies $[26,27,32-34,36,37,39,42]$. In particular, Oct4 is known to play a critical role in maintaining pluripotency and selfrenewal of the epiblast and it is down-regulated during gastrulation, suggesting that amniotic epithelium could maintain the potency of undifferentiated epiblast [32]. Nanog was only expressed at the first passages (P2 and P3) and surprisingly at P7. These data could be due to the relative heterogeneity of cells and/or to the changes in membrane expression markers that may occur from one culture passage to another, as observed by Corradetti et al. [48] in the horse. AECs did express CD44 and $C D 166$ from P3 to P9 but lacked the expression of other mesenchymal markers, as CD29, CD73 and CD90, confirming the heterogeneity observed by the proliferation studies. Bilic et al. $[48,49]$ reported that human AECs had an antigen expression profile characteristic of culture-expanded MSCs and could co-express epithelial and mesenchymal cell markers [50]. In fact, it has been reported that the amnion-derived cells have not completely differentiated into epithelial or mesenchymal phenotype, or another explanation is that the epithelial-mesenchymal transition may occur in the amniotic membrane $[49,50]$. Expression of the hematopoietic marker CD34 was not 


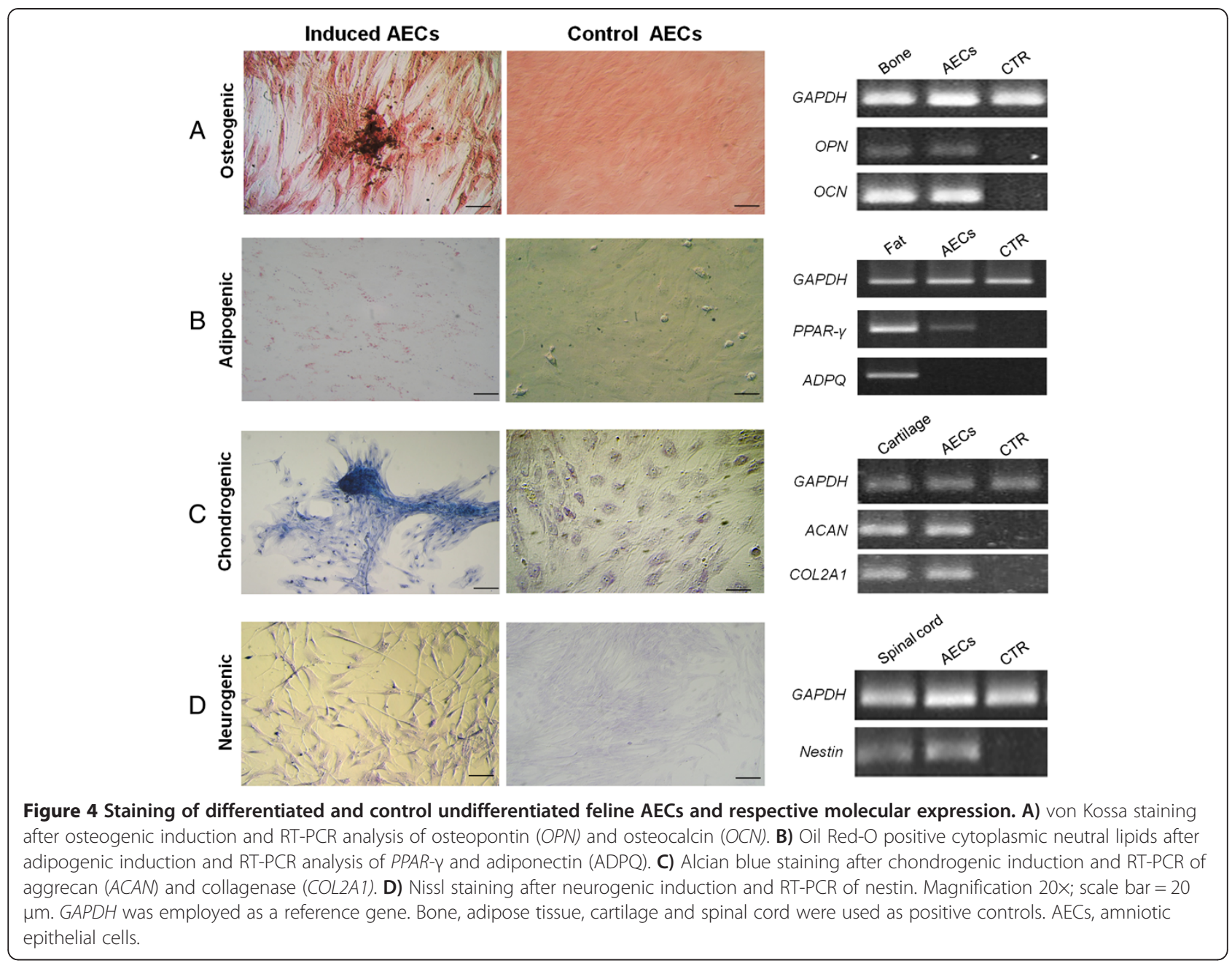

found at any passage. This result was expected, and it confirmed that isolated cells do not belong to a hematopoietic lineage. Furthermore, isolated cells seem to be immune-privileged, as confirmed by the expression of MHC-I and the absence of MHC-II expression over the passages studied. The lack of this marker hints at potential application of these cells to allo- and xeno-transplantation, in agreement with previous studies $[27,32,33,36,37,39,42,51]$.

It is important to underline that RT-PCR alone is not useful for characterizing AECs and that quantitative analysis are needed to make meaningful statements about their gene expression. The investigation with flow cytometry provides useful quantitative data on the percentage of reactivity, but, as reported by Iacono et al. [30], there are no commercially available feline speciesspecific antibodies for characterization of these MSCs.

In addition to molecular characterization by RT-PCR, we tried to detect the immunopositivity of amniotic feline epithelial cells to SSEA-3 and SSEA-4 that are cell surface globo-series glycosphingolipid epitopes that are commonly used as markers for human embryonic stem cells $[52,53]$. Lately, SSEA-3 and -4 have also been observed in MSCs from different origin [54-57]. Our data showed that $85 \%$ of cultured cells display SSEA-4 on their surface but not SSEA-3. One interpretation of these findings could be that amnion-derived cells have a subset of primitive stem cells. In this regard, it is noteworthy that the epithelial layer of horse amnion has the same epiblastic origin [58] as the human layer, and it is therefore reasonable to speculate that some AECs may have escaped the specification that accompanies gastrulation, and that these cells may retain some or all of the characteristics of epiblastic cells, such as pluripotency [32]. In contrast to SSEA-4, SSEA-3 epitope was not detected in feline AECs. Probably this result is not a surprise because it is known that SSEA-3 is extinguished more rapidly from the cell surface than SSEA-4 during embryonic stem-cell differentiation $[59,60]$.

Further investigation will be required in order to determine whether the amniotic cells, positive to some stem cell marker, are remnants of the pluripotent cells from the 
A

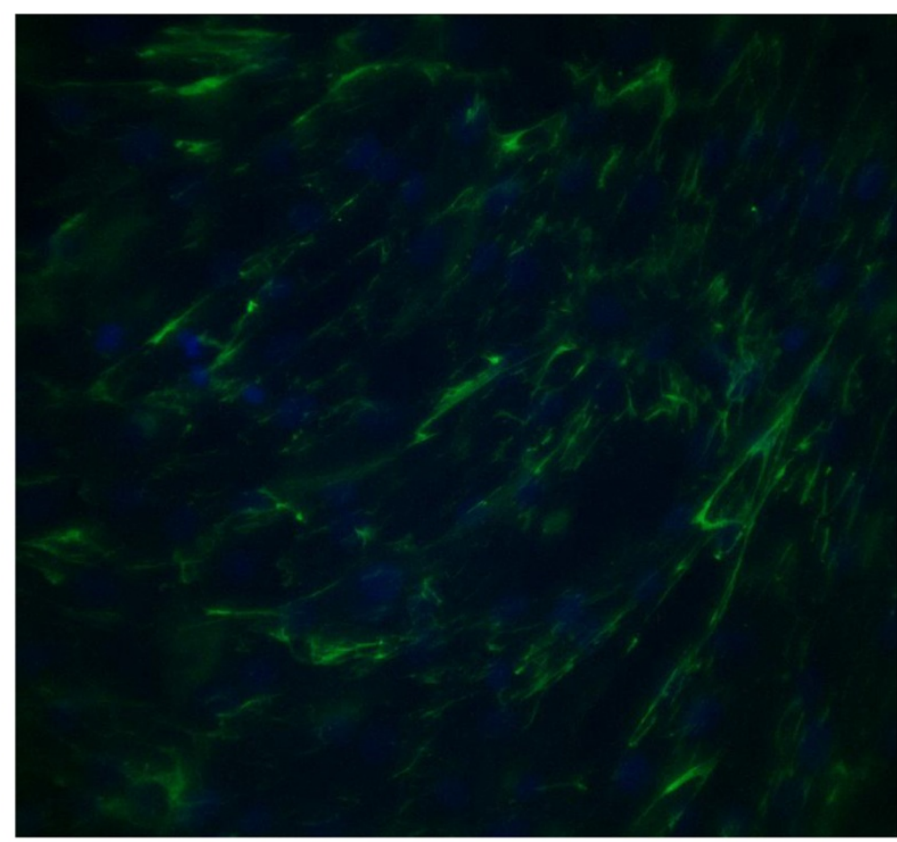

B

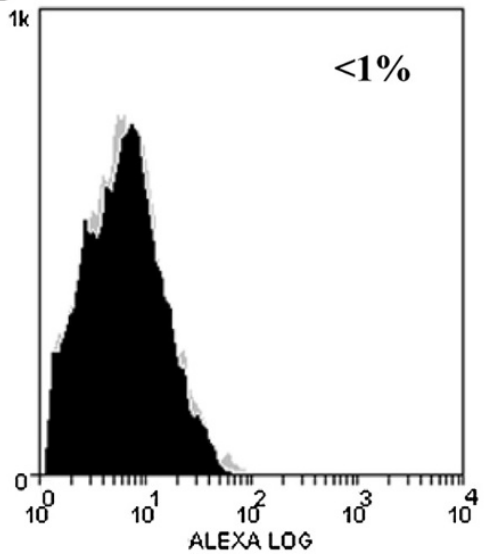

SSEA-4

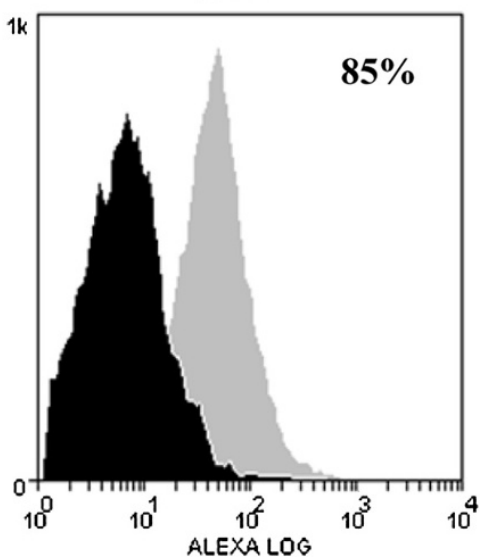

Figure 5 Immunostaining and cytometry analyses of SSEA-3 and SSEA-4 antigens. A) Photomicrographs of immunostaining of feline amniotic epithelial cells (AECs). Cells labeled with antibodies against antigen SSEA-4. Magnification 20x, scale bar = 20 mm. B) Flow cytometry analysis of SSEA-3 and SSEA-4 antigen expression with Alexafluor-488 labeled antibodies. Histograms represent relative number of cells vs. fluorescence intensity (FL1). Black histograms indicate background fluorescence intensity of cells labeled with isotype control antibodies only; gray histograms show positivity to the studied antibodies.

fetus or if amniotic cells maintain their stem cell nature for a separate and specific function which has yet to be determined. As reported by Miki and Strom [32], if placental stem cells are maintained throughout the pregnancy, the mechanism and the functional implications of this will be the basis of future exploration.

In an effort to determine the plasticity of AECs, in vitro differentiation assays have been performed and despite the lack of expression of some stem cell marker, it was possible to define feline AECs as presumptive stem cells. Nes expression, the Nissl staining and the changes in morphology observed suggested neuronal differentiation of the cells when kept under neurogenic culture condition, confirming their ability to differentiate into the ectodermal lineage. Furthermore, under in vitro induction conditions, we were able to differentiate feline AECs toward two mesodermal lineages, such as osteocytes and chondrocytes. These data were confirmed by specific gene expression analysis and specific stainings, and are in accordance with those previously reported for human, equine and ovine AECs $[26,27,33]$. When stimulated to differentiate toward the adipogenic lineage, however, AECs expressed only mRNA for $P P A R-\gamma$ that is crucial for the pre-adipocyte commitment [61]. The lack 
of expression of adiponectin, that is a collagen-like protein exclusively synthesized in white adipose tissue [62], might be led to the culture conditions employed in this study or to some specific characteristics of the feline AECs that need more time for adipogenic differentiation compared to other cell lines. Other extra-fetal cell lines, as umbilical cord blood (UCB)-derived stem cells, present much less obvious adipogenic differentiation than bone marrow- or adipose-derived MSCs [63,64]. Bieback et al. [65] did not obtain adipocytes after culture of human UCB cells in standard induction medium, containing dexamethasone, IBMX, insulin, indomethacin and FBS. However, continuous culture in induction medium for five weeks did result in some adipogenic differentiation. Similarly, only sporadic fat cells containing limited amounts of lipid droplets were evident in equine UCB cell cultures after 21 days in adipocyte induction media [66]. Lee et al. [67] achieved adipogenic differentiation but only after the addition of rabbit serum to the induction medium. Kern et al. [12] reported a failure of human UCB cells to induce differentiation into adipocytes, even following five weeks of culture.

In the effort to check pancreatic differentiation (endodermic lineages), by different protocols, differentiation was not obtained in this cell line, in our opinion due mainly to technical problems (see Additional file 1). Since these cells differentiated into two germ layers (mesodermic and ectodermic), feline AECs could be defined as multipotent, unlike human amniotic epithelial stem cells that showed pluripotency by the ability to differentiate into all three germ layers [34].

\section{Conclusions}

In conclusion, although BM-derived cells have received the most attention and are thus the best characterized, the procedure to isolate these cells requires significant time in culture and the recovery efficiency is low. This lag time prevents earlier use of these cells, which may prove to be suboptimal. AECs have no lag time in culture as they are isolated and cultured at birth or during ovario-hysterectomy. Moreover, these cells are capable of differentiation into two germ lines and have low immunogenicity, making them an ideal candidate for allogeneic implantation.

From the results obtained, it is possible to say that feline amniotic membrane, that could be collected at the delivery, during caesarean section or after ovariohysterectomy of pregnant queens, may be considered as a remarkable source of multipotent stem cells in cats, available for future efforts in cell therapy. However, further studies, including pre-clinical, and a deeper evaluation of stemness properties (as pancreatic differentiation, telomerase activity, clonal expansion, unrestricted growth, teratoma formation in mice) are needed for the in vivo applications in order to better understand their applicability for tissue regeneration in vivo and immune host reaction.

\section{Additional file}

\author{
Additional file 1: Pancreatic differentiation. Supplementary \\ information on protocols, results and discussion regarding the \\ experiments aimed to evaluate the endodermic lineage differentiation of \\ feline progenitor like amniotic epithelial cells.
}

\section{Abbreviations}

AEC: Amniotic epithelial cell; BM: Bone marrow; BSA: Bovine serum albumin; CFU: Colony forming unit; DT: Doubling time; FBS: Fetal bovine serum; FCM: Flow cytometry; HG-DMEM: High glucose-Dulbecco's modified Eagle's medium; IBMX: 3-isobutyl-methyl-xanthine; MHC: Major histocompatibility complex; MSC: Mesenchymal stem cell; P: Passage; PBS: Phosphate buffered saline; RT-PCR: Reverse transcription-polymerase chain reaction;

UCB: Umbilical cord blood.

\section{Competing interests}

The authors declare that they have no competing interests.

\section{Authors' contributions}

LR carried out the isolation and differentiation of cells, participated in molecular genetic studies and the sequence alignment, and drafted the manuscript. BC carried out the molecular genetic studies and the sequence alignment and helped in drafting the manuscript. LV and DB participated in the design of the experiments and helped in drafting the manuscript. AM participated in the isolation and differentiation of cells, and in molecular genetic studies, and sequence alignment. FC conceived of the study, participated in its design and performed the surgeries for amnion collection. ALC conceived of the study, designed and coordinated the experiments, performed the statistical analysis and drafted the manuscript. All authors have read and approved the final manuscript.

\section{Acknowledgements}

The authors wish to thank the staff of Bari University for skilled technical assistance.

This study was supported by grants from Università degli Studi di Milano and Università degli Studi "Aldo Moro" di Bari, Italy.

\section{Author details}

${ }^{1}$ Department of Emergency and Organ Transplantations, University of Bari "Aldo Moro", Bari, Italy. ²Department of Life and Environmental Sciences, Università Politecnica delle Marche, Ancona, Italy. ${ }^{3}$ Large Animal Hospital, Reproduction Unit, Università degli Studi di Milano, Lodi, Italy. ${ }^{4}$ Department of Veterinary Science for Animal Health, Production and Food Safety,

Università degli Studi di Milano, Milano, Italy

Received: 5 February 2013 Revised: 19 June 2013

Accepted: 25 October 2013 Published: 30 October 2013

\section{References}

1. Gucciardo L, Lories R, Ochsenbein-Kölble N, Done' E, Zwijsen A, Deprest J: Fetal mesenchymal stem cells: isolation, properties and potential use in perinatology and regenerative medicine. BJOG 2009, 116:166-172.

2. Menotti-Raymond M, David VA, Lyons LA, Schaffer AA, Tomlin JF, Hutton MK, O'Brien SJ: A genetic linkage map of microsatellites in the domestic cat (Felis catus). Genomics 1999, 57:9-23.

3. Narfström K, Holland Deckman K, Menotti-Raymond M: The domestic cat as a large animal model for characterization of disease and therapeutic intervention in hereditary retinal blindness. J Ophthalmol 2011, 2011:906943.

4. Shelton GD, Engvall E: Canine and feline models of human inherited muscle diseases. Neuromuscul Disord 2005, 15:127-138.

5. Stein VM, Crooks A, Ding W, Prociuk M, O'Donnell P, Bryan C, Sikora T, Dingemanse J, Vanier MT, Walkley SU, Vite CH: Miglustat improves Purkinje cell survival and alters microglial phenotype in feline Niemann-Pick disease type C. J Neuropathol Exp Neurol 2012, 71:434-448. 
6. Mizisin AP, Nelson RW, Sturges BK, Vernau KM, LeCouteur RA, Williams DC, Burgers ML, Shelton GD: Comparable myelinated nerve pathology in feline and human diabetes mellitus. Acta Neuropathol 2007, 113:431-442.

7. Linenberger ML, Abkowitz JL: Haematological disorders associated with feline retrovirus infections. Baillieres Clin Haematol 1995, 8:73-112.

8. Rohn JL, Gwynn SR, Lauring AS, Linenberger ML, Overbaugh J: Viral genetic variation, AIDS, and the multistep nature of carcinogenesis: the feline leukemia virus model. Leukemia 1996, 10:1867-1869.

9. Yu X, Jin G, Yin X, Cho S, Jeon J, Lee S, Kong I: Isolation and characterization of embryonic stem-like cells derived from in vivo-produced cat blastocysts. Mol Reprod Dev 2008, 75:1426-1432.

10. Arnhold SJ, Goletz I, Klein H, Stumpf G, Beluche LA, Rohde C, Addicks K, Litzke LF: Isolation and characterization of bone marrow-derived equine mesenchymal stem cells. Am J Vet Res 2007, 68:1095-1105

11. Fortier LA, Nixon AJ, Williams J, Cable CS: Isolation and chondrocytic differentiation of equine bone marrow-derived mesenchymal stem cells. Am J Vet Res 1998, 59:1182-1187.

12. Kern $\mathrm{S}$, Eichler $\mathrm{H}$, Stoeve J, Kluter $\mathrm{H}$, Bieback K: Comparative analysis of mesenchymal stem cells from bone marrow, umbilical cord blood, or adipose tissue. Stem Cells 2006, 24:1294-1301.

13. Mitchell KE, Weiss ML, Mitchell BM, Martin P, Davis D, Morales L, Helwig B, Beerenstrauch M, Abou-Easa K, Hildreth T, Troyer D, Medicetty S: Matrix cells from Wharton's jelly form neurons and glia. Stem Cells 2003, 21:50-60.

14. Ringe J, Kaps C, Schmitt B, Buscher K, Bartel J, Smolian H, Schultz O, Burmester GR, Haupl T, Sittinger M: Porcine mesenchymal stem cells, induction of distinct mesenchymal cell lineages. Cell Tissue Res 2002 307:321-327.

15. Smith RK, Korda M, Blunn GW, Goodship AE: Isolation and implantation of autologous equine mesenchymal stem cells from bone marrow into the superficial digital flexor tendon as a potential novel treatment. Equine Vet J 2003, 35:99-102.

16. Vidal MA, Kilroy GE, Johnson JR, Lopez MJ, Moore RM, Gimble JM: Cell growth characteristics and differentiation frequency of adherent equine bone marrow-derived mesenchymal stromal cells: adipogenic and osteogenic capacity. Vet Surg 2006, 35:601-610

17. Vidal MA, Robinson SO, Lopez MJ, Paulsen DB, Borkhsenious O, Johnson JR, Moore RM, Gimble JM: Comparison of chondrogenic potential in equine mesenchymal stromal cells derived from adipose tissue and bone marrow. Vet Surg 2008, 37:713-724.

18. Martin DR, Cox NR, Hathcock TL, Niemeyer GP, Baker HJ: Isolation and characterization of multipotential mesenchymal stem cells from feline bone marrow. Exp Hematol 2002, 30:879-886.

19. Guest DJ, Smith MR, Allen WR: Equine embryonic stem-like cells and mesenchymal stromal cells have different survival rates and migration patterns following their injection into damaged superficial digital flexor tendon. Equine Vet J 2010, 42:636-642.

20. Digirolamo CM, Stokes D, Colter D, Phinney DG, Class R, Prockop DJ: Propagation and senescence of human marrow stromal cells in culture: a simple colony-forming assay identifies samples with the greatest potential to propagate and differentiate. Br J Haematol 1999, 107:275-281.

21. Marcus AJ, Woodbury D: Fetal stem cells from extra-embryonic tissues: do not discard. J Cell Mol Med 2008, 12:730-742.

22. Pappa Kl, Anagnou NP: Novel sources of fetal stem cells: where do they fit on the developmental continuum? Regen Med 2009, 4:423-433.

23. Cremonesi F, Corradetti B, Lange Consiglio A: Fetal adnexa derived stem cells from domestic animal: progress and perspectives. Theriogenology 2011, 75:1400-1415.

24. Carlin R, Davis D, Weiss M, Schultz B, Troyer D: Expression of early transcription factors Oct-4, Sox-2 and Nanog by porcine umbilical cord (PUC) matrix cells. Reprod Biol Endocrinol 2006, 4:8.

25. Cremonesi F, Violini S: Lange Consiglio A, Ramelli P, Ranzenigo G, Mariani $P$ : Isolation, in vitro culture and characterization of foal umbilical cord stem cells at birth. Vet Res Commun 2008, 32:S139-S142.

26. Díaz-Prado S, Muiños-López E, Hermida-Gómez T, Cicione C, Rendal-Vázquez ME, Fuentes-Boquete I, de Toro FJ, Blanco FJ: Human amniotic membrane as an alternative source of stem cells for regenerative medicine. Differentiation 2011, 81:162-171.

27. Lange-Consiglio A, Corradetti B, Bizzaro D, Magatti M, Ressel L, Tassan S, Parolini O, Cremonesi F: Characterization and potential applications of progenitor-like cells isolated from horse amniotic membrane. J Tissue Eng Regen Med 2012, 6:622-635.
28. Mauro A, Turriani M, loannoni A, Russo V, Martelli A, Di Giacinto O, Nardinocchi D, Berardinelli P: Isolation, characterization, and in vitro differentiation of ovine amniotic stem cells. Vet Res Commun 2010, 34:1.

29. Filioli Uranio M, Valentini L, Lange-Consiglio A, Caira M, Guaricci AC, L'Abbate A, Catacchio CR, Ventura M, Cremonesi F, Dell'Aquila ME: Isolation, proliferation, cytogenetic, and molecular characterization and in vitro differentiation potency of canine stem cells from foetal adnexa: a comparative study of amniotic fluid, amnion, and umbilical cord matrix. Mol Reprod Dev 2011, 78:361-373.

30. lacono E, Cunto M, Zambelli D, Ricci F, Tazzari PL, Merlo B: Could fetal fluid and membranes be an alternative source for mesenchymal stem cells (MSCs) in the feline species? A preliminary study. Vet Res Commun 2012, 36:107-118.

31. Vejlsted M: Gastrulation, body folding and coelom formation. In Essentials of Domestic Animals Embryology. Edited by Hyttel P, Sinowatz F, Vejlsted M. London, New York, Oxford, Philadelphia, St Louis, Sydney, Toronto: Saunders/Elsevier; 2010:79-95.

32. Miki T, Strom S: Amnion-derived pluripotent/multipotent stem cells. Stem Cell Rev 2006, 2:133-142.

33. Ilancheran S, Michalska A, Peh G, Wallace EM, Pera M, Manuelpillai U: Stem cells derived from human fetal membranes display multilineage differentiation potential. Biol Reprod 2007, 77:577-588.

34. Miki T, Lehmann T, Cai H, Stolz DB, Strom SC: Stem cell characteristics of amniotic epithelial cells. Stem Cells 2005, 23:1549-1559.

35. Miki T, Mitamura K, Ross M, Stolz D, Strom S: Identification of stem cell marker-positive cells by immunofluorescence in term human amnion. J Reprod Immunol 2007, 75:91-97.

36. Parolini $O$, Alviano F, Bagnara GP, Bilic G, Bühring H-J, Evangelista $M$, Hennerbichler S, Liu B, Magatti M, Mao N, Miki T, Marongiu F, Nakajima H, Nikaido T, Portmann-Lanz CB, Sankar V, Soncini M, Stadler G, Surbek D, Takahashi TA, Redl H, Sakuragawa N, Wolbank S, Zeisberger S, Zisch A, Strom SC: Concise review: isolation and characterization of cells from human term placenta: outcome of the first international workshop on placenta derived stem cells. Stem Cells 2007, 26:300-311.

37. Mattioli M, Gloria A, Turriani M, Mauro A, Curini V, Russo V, Tete S, Marchisio M, Pierdomenico L, Berardinelli P, Colosimo A, Muttini A, Valbonetti L, Barboni B: Stemness characteristics and osteogenic potential of sheep amniotic epithelial cells. Cell Biol Int 2012, 36:7-19.

38. Miki T, Marongiu F, Dorko K, Ellis E, Strom S: Isolation of amniotic epithelial stem cells. Curr Protoc Stem Cell Biol 2010, 12:1E.3.1-1E.3.10.

39. Toda A, Okabe M, Yoshida T, Nikaido T: The potential of amniotic membrane/amnion-derived cells for regeneration of various tissues. J Pharmacol Sci 2007, 105:215-228.

40. Insausti $\mathrm{CL}$, Blanquer M, Bleda P, Iniesta P, Majado MJ, Castellanos G, Moraleda JM: The amniotic membrane as a source of stem cells. Histol Histopathol 2010, 25:91-98

41. Parolini $\mathrm{O}$, Soncini M: Human placenta: a source of progenitor/stem cells? J. Reproduktionsmed Endokrinol 2006, 3:117-126.

42. Evangelista M, Soncini M, Parolini O: Placenta-derived stem cells: new hope for cell therapy? Cytotechnology 2008, 58:33-42.

43. Li H, Niederkorn J, Neelam S, Mayhew E, Word R, McCulley J, Alizadeh H: Immunosuppressive factors secreted by human amniotic epithelial cells. Invest Ophthalmol Vis Sci 2005, 46:900-907.

44. Bailo M, Soncini M, Vertua E, Signoroni PB, Sanzone S, Lombardi G, Arienti D, Calamani F, Zatti D, Paul P, Albertini A, Zorzi F, Cavagnini A, Candotti F, Wengler GS, Parolini O: Engraftment potential of human amnion and chorion cells derived from term placenta. Transplantation 2004, 78:1439-1448.

45. Gómez MC, Serrano MA, Pope CE, Jenkins JA, Biancardi MN, López M, Dumas C, Galiguis J, Dresser BL: Derivation of cat embryonic stem-like cells from in vitro-produced blastocysts on homologous and heterologous feeder cells. Theriogenology 2010, 74:498-515.

46. Walter+Eliza Hall Institute of Medical Research: Weasel software (version 2.5)). http://www.wehi.edu.au/other_domains/cytometry/ WeaselDownload.php.

47. Sarugaser R, Lickorish D, Baksh D, Hosseini MM, Davies JE: Human umbilical cord perivascular (HUCPV) cells: a source of mesenchymal progenitors. Stem Cells 2005, 23:220-229.

48. Corradetti B, Lange-Consiglio A, Barucca M, Cremonesi F, Bizzaro D: Size-sieved subpopulations of mesenchymal stem cells from intervascular and perivascular equine umbilical cord matrix. Cell Prolif 2011, 44:330-342. 
49. Bilic G, Zeisberger SM, Mallik AS, Zimmermann R, Zisch AH: Comparative characterization of cultured human term amnion epithelial and mesenchymal stromal cells for application in cell therapy. Cell Transplant 2008, 17:955-968.

50. Sakuragawa N, Kakinuma K, Kikuchi A, Okano H, Uchida S, Kamo I, Kobayashi M, Yokoyama Y: Human amnion mesenchyme cells express phenotypes of neuroglial progenitor cells. J Neurosci Res 2004, 78:208-214.

51. Muttini A, Valbonetti L, Abate M, Colosimo A, Curini V, Mauro A, Berardinelli P, Russo V, Cocciolone D, Marchisio M, Mattioli M, Tosi U, Podaliri Vulpiani M, Barboni B: Ovine amniotic epithelial cells: in vitro characterization and transplantation into equine superficial digital flexor tendon spontaneus defects. Res Vet Sci 2013, 94:158-169.

52. Muramatsu T, Muramatsu H: Carbohydrate antigens expressed on stem cells and early embryonic cells. Glycoconj J 2004, 21:41-45.

53. Wright AJ, Andrews PW: Surface marker antigens in the characterization of human embryonic stem cells. Stem Cell Res 2009, 3:3-11.

54. Gang EJ, Bosnakovski D, Figueiredo CA, Visser JW, Perlingeiro RC: SSEA-4 identifies mesenchymal stem cells from bone marrow. Blood 2007, 109:1743-1751.

55. Guillot PV, Gotherstrom C, Chan J, Kurata H, Fisk NM: Human first-trimester fetal MSC express pluripotency markers and grow faster and have longer telomeres than adult MSC. Stem Cells 2007, 25:646-654.

56. Sun B, Roh KH, Lee SR, Lee YS, Kang KS: Induction of human umbilical cord blood-derived stem cells with embryonic stem cell phenotypes into insulin producing islet-like structure. Biochem Biophys Res Commun 2007, 354:919-923.

57. Sobiesiak M, Sivasubramaniyan K, Hermann C, Tan C, Orgel M, Treml S, Cerabona F, de Zwart P, Ochs U, Muller CA, Gargett CE, Kalbacher H, Buhring $\mathrm{HJ}$ : The mesenchymal stem cell antigen MSCA-1 is identical to tissue non-specific alkaline phosphatase. Stem Cells Dev 2010, 19:669-677.

58. Vejlsted M: Comparative placentation. In Essentials of Domestic Animal Embryology. Edited by Hyttel P. Edinburgh, New York: Saunders/Elsevier; 2010:104-119.

59. Draper JS, Pigott C, Thomson JA, Andrews PW: Surface antigens of human embryonic stem cells: changes upon differentiation in culture. J Anat 2002, 200:249-258.

60. Brimble SN, Sherrer ES, Uhl EW, Wang E, Kelly S, Merrill AH Jr, Robins AJ, Schulz TC: The cell surface glycosphingolipids SSEA-3 and SSEA-4 are not essential for human ESC pluripotency. Stem Cells 2007, 25:54-62.

61. Tontonoz P, Hu E, Graves RA, Budavari Al, Spiegelman BM: mPPAR gamma 2: tissue-specific regulator of an adipocyte enhancer. Genes Dev 1994 8:1224-1234.

62. Chandran M, Phillips SA, Ciaraldi T, Henry RR: Adiponectin: more than just another fat cell hormone? Diabetes Care 2003, 26:2442-2450.

63. Wagner W, Wein F, Seckinger A, Frankhauser M, Wirkner U, Krause U, Blake J, Schwager C, Eckstein V, Ansorge W, Ho AD: Comparative characteristics of mesenchymal stem cells from human bone marrow, adipose tissue, and umbilical cord blood. Exp Hematol 2005, 33:1402-1416.

64. Rebelatto CK, Aguiar AM, Moretao MP, Senegaglia AC, Hansen P, Barchiki F, Oliveira J, Martins J, Kuligovski C, Mansur F, Christofis A, Amaral VF, Brofman PS, Goldenberg S, Nakao LS, Correa A: Dissimilar differentiation of mesenchymal stem cells from bone marrow, umbilical cord blood, and adipose tissue. Exp Biol Med (Maywood) 2008, 233:901-913.

65. Bieback K, Kern S, Kluter $\mathrm{H}$, Eichler $\mathrm{H}$ : Critical parameters for the isolation of mesenchymal stem cells from umbilical cord blood. Stem Cells 2004, 22:625-634

66. Reed SA, Johnson SE: Equine umbilical cord blood contains a population of stem cells that express Oct4 and differentiate into mesodermal and endodermal cell types. J Cell Physio/ 2008, 215:329-336.

67. Lee OK, Kuo TK, Chen WM, Lee KD, Hsieh SL, Chen TH: Isolation of multipotent mesenchymal stem cells from umbilical cord blood. Blood 2004, 103:1669-1675.

doi:10.1186/scrt344

Cite this article as: Rutigliano et al:: Molecular characterization and in vitro differentiation of feline progenitor-like amniotic epithelial cells. Stem Cell Research \& Therapy 2013 4:133.

\section{Submit your next manuscript to BioMed Central and take full advantage of:}

- Convenient online submission

- Thorough peer review

- No space constraints or color figure charges

- Immediate publication on acceptance

- Inclusion in PubMed, CAS, Scopus and Google Scholar

- Research which is freely available for redistribution

Submit your manuscript at www.biomedcentral.com/submit
( BioMed Central 